\title{
ANTIFOULING PROPERTIES OF CONDUCTIVE RUBBER COATINGS USED FOR FISHING NETS
}

\author{
Jer-Ruey Huang \\ Institute of Materials Engineering, National Taiwan Ocean University, Keelung 20248, Taiwan, R.O.C. \\ Wei-Ting Lin \\ Department of Harbor and River Engineering, National Taiwan Ocean University, Keelung 20248, Taiwan, R.O.C. \\ Ran Huang \\ Department of Harbor and River Engineering, National Taiwan Ocean University, Keelung 20248, Taiwan, R.O.C. \\ Jiann-Kuo Wu \\ Institute of Materials Engineering, National Taiwan Ocean University, Keelung 20248, Taiwan, R.O.C., \\ A0055@ntou.edu.tw
}

Follow this and additional works at: https://jmstt.ntou.edu.tw/journal

Part of the Civil and Environmental Engineering Commons

\section{Recommended Citation}

Huang, Jer-Ruey; Lin, Wei-Ting; Huang, Ran; and Wu, Jiann-Kuo (2009) "ANTIFOULING PROPERTIES OF CONDUCTIVE RUBBER COATINGS USED FOR FISHING NETS," Journal of Marine Science and Technology. Vol. 17: Iss. 3, Article 3. DOI: $10.51400 / 2709-6998.1954$

Available at: https://jmstt.ntou.edu.tw/journal/vol17/iss3/3

This Research Article is brought to you for free and open access by Journal of Marine Science and Technology. It has been accepted for inclusion in Journal of Marine Science and Technology by an authorized editor of Journal of Marine Science and Technology. 


\section{ANTIFOULING PROPERTIES OF CONDUCTIVE RUBBER COATINGS USED FOR FISHING NETS}

\section{Acknowledgements}

The authors are grateful to Mr. Wen-Chi Chiang, Mr. ShangJu Liu and Mr. Chien-Chung Chen who participated in this study together, and financial sponsored of this research by the Council of Agriculture, Taiwan (Contract No. 93AS-9.1.1-F1- 21). 


\title{
ANTIFOULING PROPERTIES OF CONDUCTIVE RUBBER COATINGS USED FOR FISHING NETS
}

\author{
Jer-Ruey Huang*, Wei-Ting Lin**, Ran Huang**, and Jiann-Kuo Wu*
}

Key words: antifouling, conductive coatings, fishing net, conductive rubber.

\begin{abstract}
The purpose of the present study is to develop a new conductive coating for application on fishing nets that can be used as an anode, while submersed in the sea, to generate free chlorine which will in turn inhibit marine biofouling. To confirm the durability and viability of this coating, long-term field tests were carried out in the Nanao harbor in Taiwan. Electrical resistivity tests showed that conductive rubber with a polyaniline coating demonstrates the lowest resistivity: 0.11 $\Omega \mathrm{m}$. This sample also generated optimal quantities of free chlorine, which demonstrates antifouling properties. The use of carbon black in conjunction with polyaniline did not prove to yield greater benefits. A 500 day field test showed that the CR-P-N conductive coatings reduced the quantity of marine biofouling attached to the cage by approximately 53\%. Furthermore, the chlorine produced was within safe levels, and judged not to pollute the sea.
\end{abstract}

\section{INTRODUCTION}

Cage aquaculture and set-net fishery are widely used in fishing industry, but have problems associated with marine biofouling pollution which reduces cage aquaculture efficiency, fishing net life and increases the service costs. Traditional marine antifouling techniques involve the addition of chlorine or the use of antifouling. While chlorine addition is efficient, there is a risk of either corroding equipment or poisoning marine life $[1,14]$. Antifouling coatings are also good inhibitors, but they often contain copper or organic metal compounds which are toxic to the marine environment [9]. In 2008 the international marine organization prohibited the use of surface paints which contain tri-butyl tin (TBT) [2]. Alternative, nontoxic paint compounds or low surface tensions have been studied, including silicic acid used to prevent bio-

Author for correspondence: Jiann-Kuo Wu (e-mail: A0055@ntou.edu.tw). *Institute of Materials Engineering, National Taiwan Ocean University, Keelung 20248, Taiwan, R.O.C.

**Department of Harbor and River Engineering, National Taiwan Ocean University, Keelung 20248, Taiwan, R.O.C. fouling as well [9], fluoro-polyurethane [15], polyurethane [10] and perfluorinated polymers [11].

Prior to our study, conductive silicate coatings have been applied to power plant chilled water pipes in order to inhibit biofouling [3]. Furthermore, recent studies have also suggested chlorine-based electrolysis technologies [8] as a possible substitution for traditional antifouling methods.

Electrolysis within seawater using a platinum or graphite electrode leads to complex chemical reactions. For simplicity we provide the reactions involved when electrolysis is conducted in an electrobath $[7,13,16]$. These reactions that occur at the anode and cathode are shown in the following equations.

Anodic reaction:

$$
2 \mathrm{Cl}_{(\text {aq })}^{-} \rightarrow \mathrm{Cl}_{2(\mathrm{~g})}+2 \mathrm{e}^{-}
$$

Cathodic reaction:

$$
2 \mathrm{H}^{+}{ }_{(\mathrm{aq})}+2 \mathrm{e}^{-} \rightarrow \mathrm{H}_{2(\mathrm{~g})}
$$

When $\mathrm{Cl}_{2}$ dissolves in the seawater, a reaction occurs as following equations:

$$
\mathrm{Cl}_{2(\mathrm{~g})}+\mathrm{H}_{2} \mathrm{O} \rightarrow \mathrm{HClO}_{(\mathrm{aq})}+\mathrm{HCl}_{(\mathrm{aq})}
$$

Providing that there is a suitable electrical current the anode generates a concentration of hypochlorite ions $\left(\mathrm{ClO}^{-}\right)$and hypochlorous acid $(\mathrm{HClO})$ which will inhibit biofouling. Both of these species can be regarded as free chlorine. The hypochlorite ion and hypochlorous acid solution will establish the following equilibrium:

$$
\mathrm{HClO}=\mathrm{H}^{+}+\mathrm{ClO}^{-}
$$

The equilibrium concentrations are dependent on $\mathrm{pH}$. Figure 1 [16] shows the effect of $\mathrm{pH}$ on the percentage concentrations of hypochlorite ion and hypochlorous acid. Since the $\mathrm{pH}$ of seawater is approximately 8 , the free chlorine is predominantly present in the form of hypochlorite ions. In solution, ammonia or organic nitrogen-containing compounds can react with the hypochlorous acid to form $\mathrm{NH}_{2} \mathrm{Cl}, \mathrm{NH}_{2} \mathrm{Cl}_{2}$ and $\mathrm{NCl}_{3}$, which will henceforth be referred to as combined chlorine. The reactions are as follows: 


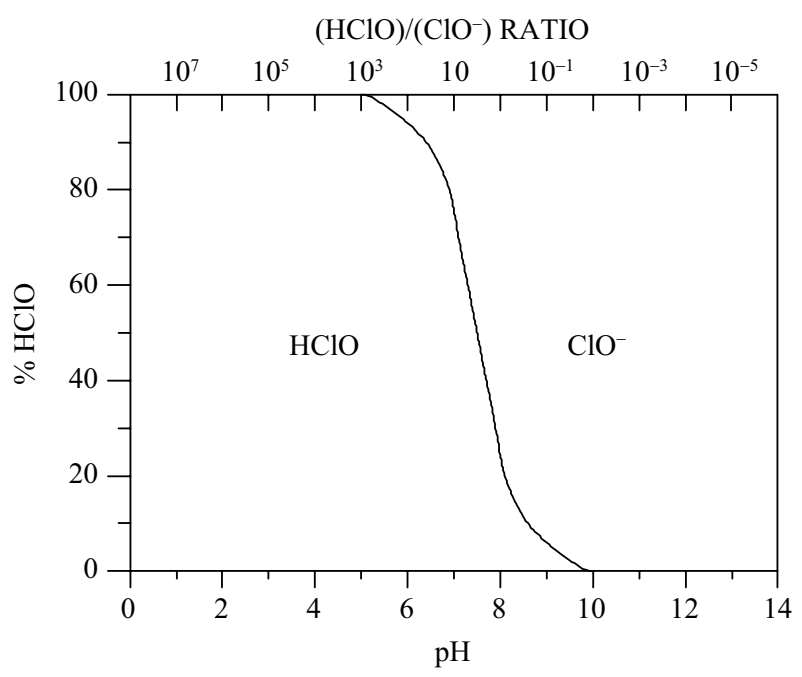

Fig. 1. The effect of $\mathrm{pH}$ on the percentage of hypochlorite ions and hypochlorous acid [10].

$$
\begin{gathered}
\mathrm{NH}_{3}+\mathrm{HClO} \rightarrow \mathrm{H}_{2} \mathrm{O}+\mathrm{NH}_{2} \mathrm{Cl} \\
\mathrm{NH}_{2} \mathrm{Cl}+\mathrm{HClO} \rightarrow \mathrm{H}_{2} \mathrm{O}+\mathrm{NH}_{2} \mathrm{Cl}_{2} \\
\mathrm{NH}_{2} \mathrm{Cl}+\mathrm{HClO} \rightarrow \mathrm{H}_{2} \mathrm{O}+\mathrm{NCl}_{3}
\end{gathered}
$$

The sum of the free chlorine and the combined chlorine is known as the total chlorine or total residual chlorine. Free chlorine can act as a fungicide and inhibit marine biofouling, effectively preventing substances from attaching to metals. Free chlorine is a far more efficient sterilization agent than combined chlorine. Figure 2 shows a schematic of the conductive coatings that are used to generate free chlorine in electrolysis.

According to the study produced by Mitsubishi Heavy Industries [12], it has been confirmed that marine biofouling can be inhibited when the free chlorine concentration enclosing the structures, at a distance of $50-100 \mu \mathrm{m}$, is set to $0.05-0.1$ ppm. Gunderson [8] pointed out that the concentration of hypochlorite enclosing the structure at a distance of $10 \mu \mathrm{m}$ should be kept at 0.1-0.3 ppm in order to inhibit biofouling. Oldfield [13] studied alkyd resin conductive coatings applied to cooling water piping of power plants to control metal corrosion.

The purpose of present study is to develop a new conductive coating on fishing net. Electrical resistivity measurement and electrolysis test were carried out to study the optimal conductive coating system. Long term field tests were performed to investigate the antifouling ability and durability of our developed conductive coating.

\section{EXPERIMENTAL METHOD}

The experiment can be divided into two stages: (i) development of the conductive coating in the laboratory in order to

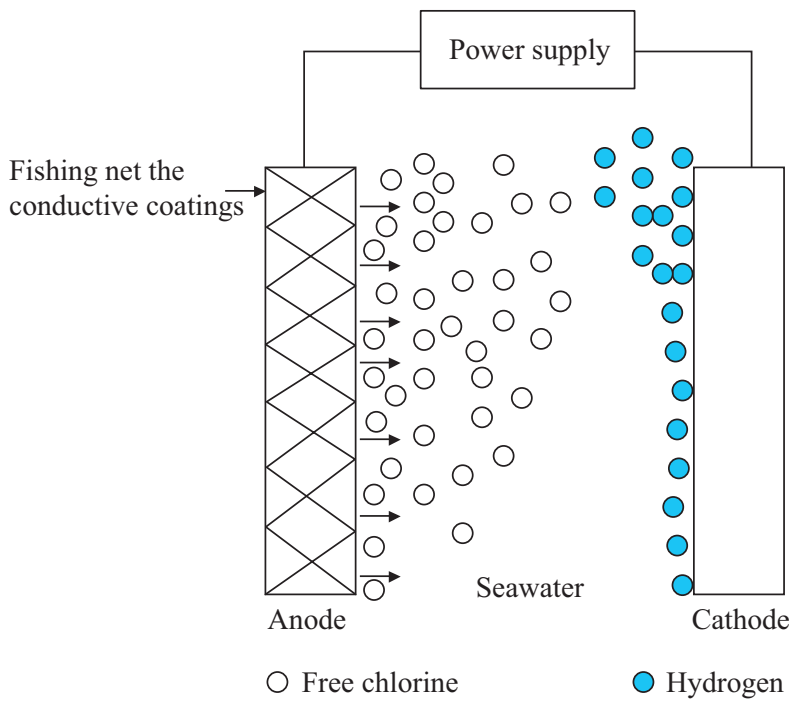

Fig. 2. The fundamental components and procedure for generating chlorine by using electrolysis.

establish the optimal coating and (ii) field testing and evaluation of the coating's ability to inhibit marine biofouling and its endurance.

\section{Materials}

Rubber and polyvinyl rubber resins diluted in xylene were used in the laboratory tests. Either carbon black (average grain diameter $20 \mu \mathrm{m}$ ) or polyaniline were used as additives. Polyaniline was synthesized by reacting aniline $\left(\mathrm{C}_{6} \mathrm{H}_{5} \mathrm{NH}_{2}\right)$ and ammonium peroxodisulfate $\left(\left(\mathrm{NH}_{4}\right) \mathrm{S}_{2} \mathrm{O}_{8}\right)$ in hydrochloric acid $(\mathrm{HCl})$.

\section{Preparation of the Conductive Coatings}

Both resins were used to bind the coatings by stirring with carbon black and/or polyaniline to create a uniform mixture. Two coats of the mixture were sprayed onto substrates. The substrates were steel plates and fishing nets (black polyethylene, $20 \mathrm{~mm}$ mesh, $2.4 \mathrm{~mm}$ diameter). The film thickness was controlled to within $250-300 \mu \mathrm{m}$. In order to measure the electrical resistivity electrolysis tests were carried out 72 hours after the application of the second coat.

\section{Electrical Resistivity Measurement}

The electrical resistivity of the conductive coating was obtained using Ohm's law:

$$
\boldsymbol{\rho}=\mathbf{R} \cdot \mathbf{A} / \boldsymbol{l}
$$

Where $\rho$ is the electrical resistivity $(\Omega \mathrm{m}), \mathrm{R}$ is the electrical resistance $(\Omega)$, A is the cross-sectional area $\left(\mathrm{m}^{2}\right)$ and $l$ is the length $(\mathrm{m})$. The electrical resistivity readings were averaged over five repeat tests.

\section{Electrolysis Test in the Laboratory}

This test evaluates the effectiveness of the coating to inhibit 


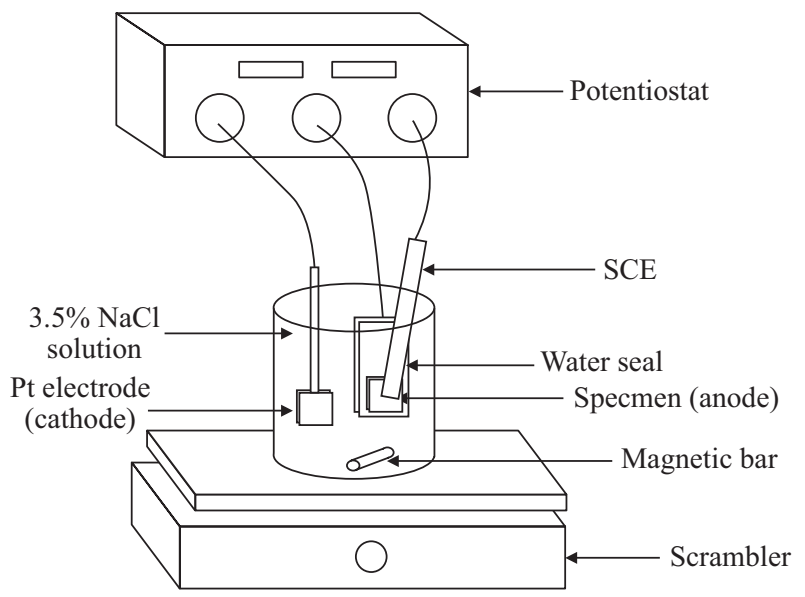

Fig. 3. Schematic design of the electro-bath used for the electrolysis test.

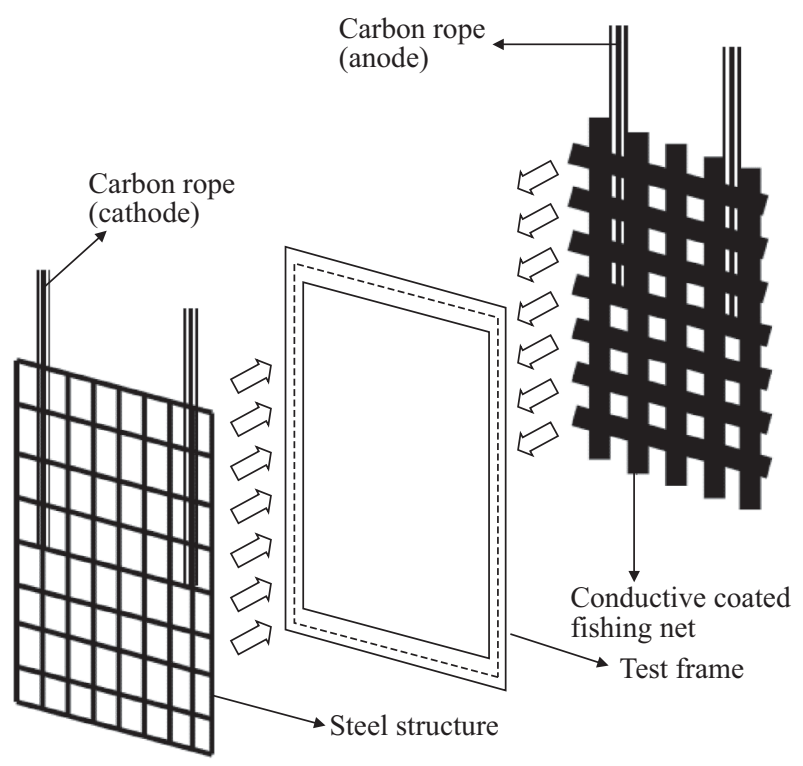

Fig. 4. Schematic design of field test.

biofouling by electrochemical disinfection with newly developed conductive electrodes that have high concentrations of free chlorine. The electrobath used in the electrolysis test consisted of a conductive, coated electrode (the working electrode), a platinum electrode (the counter electrode), and a saturated calomel electrode (the reference electrode) and is depicted in Fig. 3. The test was undertaken in $3.5 \% \mathrm{NaCl}$ solution with stirring, using a scrambler to keep the free chlorine distribution uniform. The potential at the anode was held constant anodic potential (4 V, SCE) using a potentiostat. Data were presented as current density as a function of time.

The concentration of free chlorine was measured using a spectrophotometer (Lamotte Co. $1200 \mathrm{CL}$ ). $10 \mathrm{~mL}$ samples from the bath were put into the developer (N-diethyl-pphenylenediamine, DPD) immediately; the luminosity of the developed image was interpreted using the spectrophotometer.

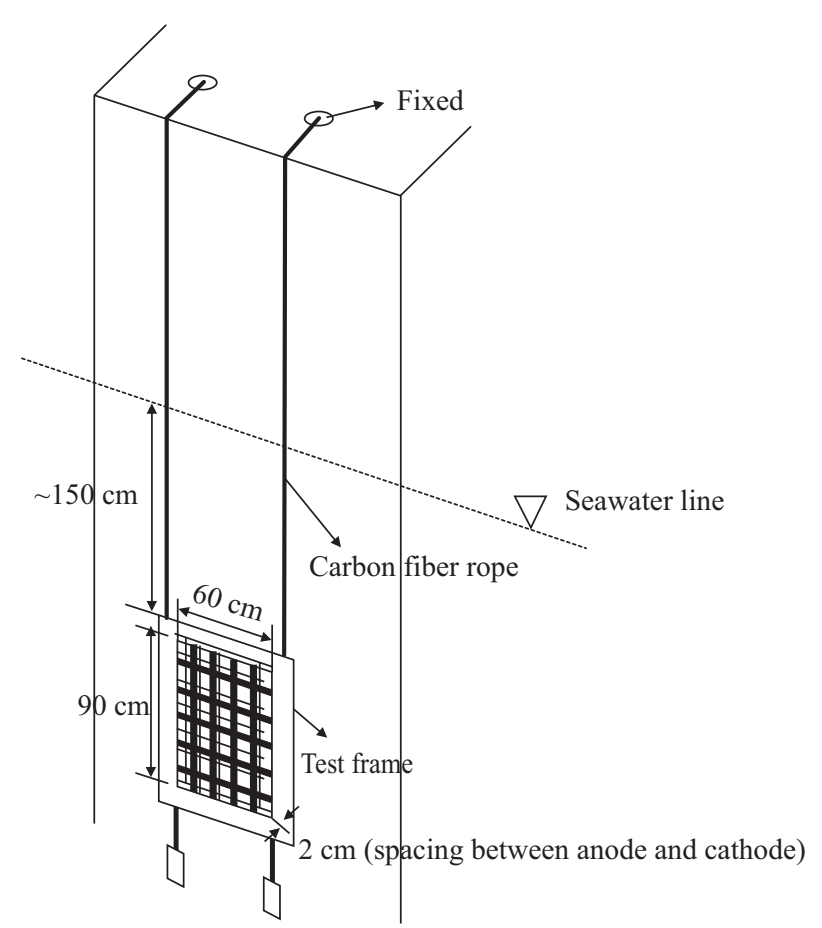

Fig. 5. Erection schematic of field test.

\section{Field Test}

Long term field tests were carried out in the Nanao harbor in Taiwan. Figure 4 shows the field test design. The conductive coated fishing net acts as the anode, the control is a bare fishing anode and the wire netting is used as the cathode. Figure 5 is a schematic of the frame installation. Regular measurements of the concentration of free chlorine and the total chlorine were carried out at a distance of $10-15 \mathrm{~cm}$ from the coating surface. $10 \mathrm{~mL}$ samples were put into the developer immediately, the concentration of free chlorine and the total chlorine was measured using the spectrophotometer.

\section{RESULTS AND DISCUSSION}

\section{Electrical Resistivity}

The conductive additives used in this study were carbon black and polyaniline. The latter is a suitable conducting material that can inhibit marine biofouling [17] and can enhance the conductivity of the material $[4,6]$.

Table 1 shows the results of the electrical resistivity tests; the resistivities of the fishing nets were found to be about $30-50 \%$ higher than the steel plates. This difference may be largely due to the complex geometry of the fishing nets, as well as uneven film thickness over the sample. Furthermore the coating may have cracked or flaked during drying, causing the conductivity to decrease.

Conductive rubber without additives on the fishing net had a resistivity of $0.26 \Omega \mathrm{m}$; this is the lowest value, compared 
Table 1. Specimen designations, composition and electrical resistivities.

\begin{tabular}{|c|c|c|c|c|c|}
\hline \multirow{2}{*}{ Specimen designations } & \multirow{2}{*}{ Resin type } & \multicolumn{2}{|c|}{ Conductive additive (wt $\%$ ) } & \multirow{2}{*}{ Substrate } & \multirow{2}{*}{$\begin{array}{c}\text { Electrical resistivity } \\
(\Omega \mathrm{m})\end{array}$} \\
\hline & & Carbon black & Polyaniline & & \\
\hline CR-S & \multirow{8}{*}{ Conductive rubber } & 0 & 0 & \multirow{4}{*}{ Steel plate } & 0.17 \\
\hline CR-C-S & & 10 & 0 & & 0.07 \\
\hline CR-P-S & & 0 & 10 & & 0.05 \\
\hline CR-CP-S & & 5 & 5 & & 0.09 \\
\hline CR-N & & 0 & 0 & \multirow{4}{*}{ Fishing net } & 0.26 \\
\hline CR-C-N & & 10 & 0 & & 0.13 \\
\hline CR-P-N & & 0 & 10 & & 0.11 \\
\hline CR-CP-N & & 5 & 5 & & 0.14 \\
\hline VR-C-S & \multirow{6}{*}{ Polyvinyl rubber } & 10 & 0 & \multirow{3}{*}{ Steel plate } & 1.09 \\
\hline VR-P-S & & 0 & 10 & & 0.25 \\
\hline VR-CP-S & & 5 & 5 & & 0.75 \\
\hline VR-C-N & & 10 & 0 & \multirow{3}{*}{ Fishing net } & 1.88 \\
\hline VR-P-N & & 0 & 10 & & 0.33 \\
\hline VR-CP-N & & 5 & 5 & & 1.37 \\
\hline
\end{tabular}

Table 2. Laboratory electrolysis results.

\begin{tabular}{|c|c|c|c|c|}
\hline Specimen designations & Initial current density $\left(\mathrm{mA} / \mathrm{cm}^{2}\right)$ & $\begin{array}{c}\text { Steady state current density } \\
\left(\mathrm{mA} / \mathrm{cm}^{2}\right)\end{array}$ & $\mathrm{pH}$ & $\begin{array}{c}\text { Free chlorine concentration } \\
(\mathrm{ppm})\end{array}$ \\
\hline CR-C-N & 0.72 & 0.10 & \multirow{3}{*}{$9-10$} & 52 \\
\hline CR-P-N & 0.94 & 0.17 & & 60 \\
\hline CR-CP-N & 0.57 & 0.09 & & 48 \\
\hline
\end{tabular}

with polyvinyl rubber when coated with $10 \%$ carbon black $(0.19 \Omega \mathrm{m}), 10 \%$ polyaniline $(0.33 \Omega \mathrm{m})$, and $5 \%$ carbon black with $5 \%$ polyaniline $(1.37 \Omega \mathrm{m})$. Clearly the conductive rubber alone is the best electrical conductor.

When comparing the effects of carbon and polyaniline on the conductive rubber, the results demonstrated the following resistivities: $10 \%$ carbon black, $0.13 \Omega \mathrm{m} ; 10 \%$ polyaniline, $0.11 \Omega \mathrm{m}$; and $5 \%$ carbon black $/ 5 \%$ polyaniline, $0.14 \Omega \mathrm{m}$. The electrical resistivity value of conductive rubber coated with $5 \%$ carbon black and 5\% polyaniline was $0.14 \Omega \mathrm{m}$ and is higher than with $10 \%$ polyaniline $(0.11 \Omega \mathrm{m})$, so we see there is no advantage to the simultaneous addition of carbon black and polyaniline. This result is analogous with the polyvinyl rubber results. However when coated, both the conductive and polyvinyl rubbers have better electrical conductivity. Conductive rubber with $10 \%$ polyaniline coating (CR-P-N) had the best electrical conductivity in this study.

\section{Electrolysis Experiment}

The electrolysis experiment used the above investigation to select the lower resistivity samples CR-C-N, CR-P-N and CR-CP-N; then immersed a $15 \mathrm{~cm}^{2}$ sample into the $3.5 \% \mathrm{NaCl}$ solution. The values of the initial current density and steady current density are listed in Table 2. Figure 6 shows the relation between current density and the immersion time in the salt solution.

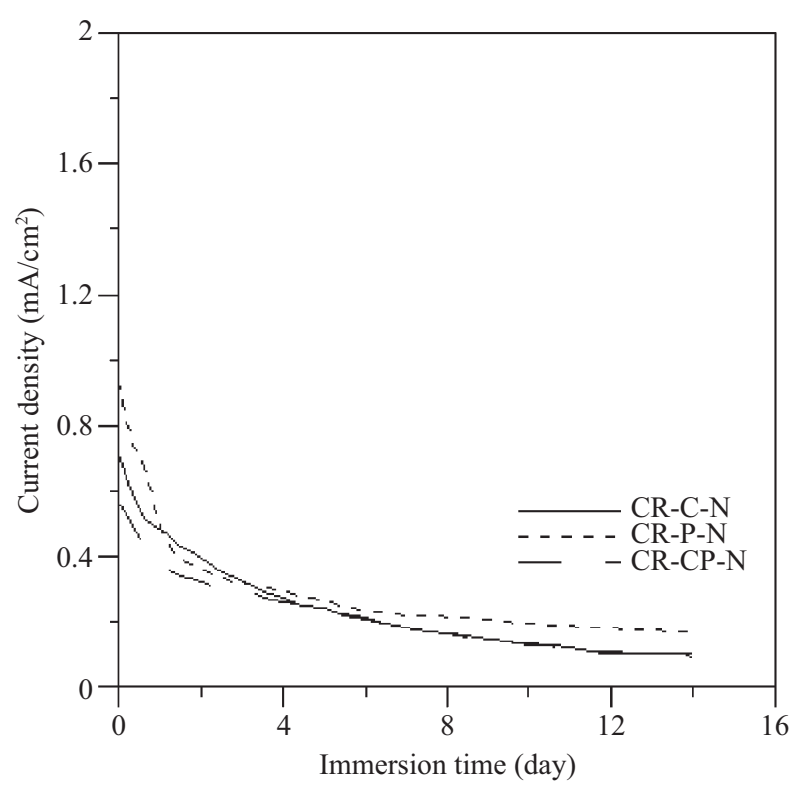

Fig. 6. Current density at a constant anodic potential (4 V, SCE) for conductive coatings in $3.5 \% \mathrm{NaCl}$ solution.

Results show that the initial current densities of the CR-P-N, CR-C-N and CR-CP-N samples were 0.942, 0.716 and 0.565 $\mathrm{mA} / \mathrm{cm}^{2}$ respectively; the steady state current densities were 


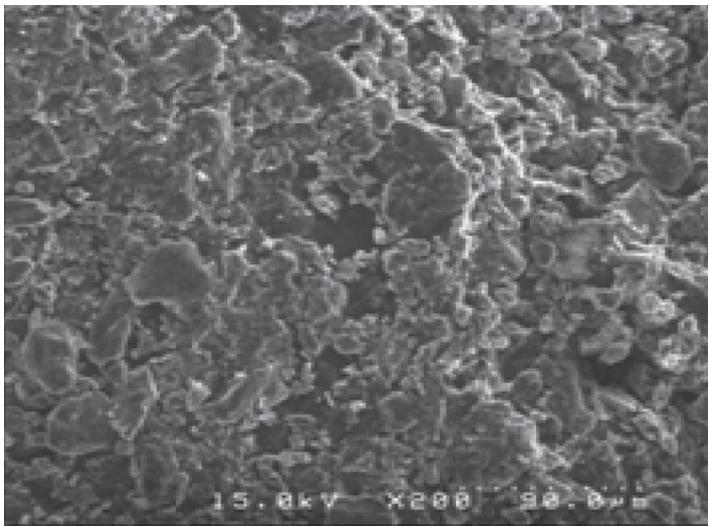

(a)

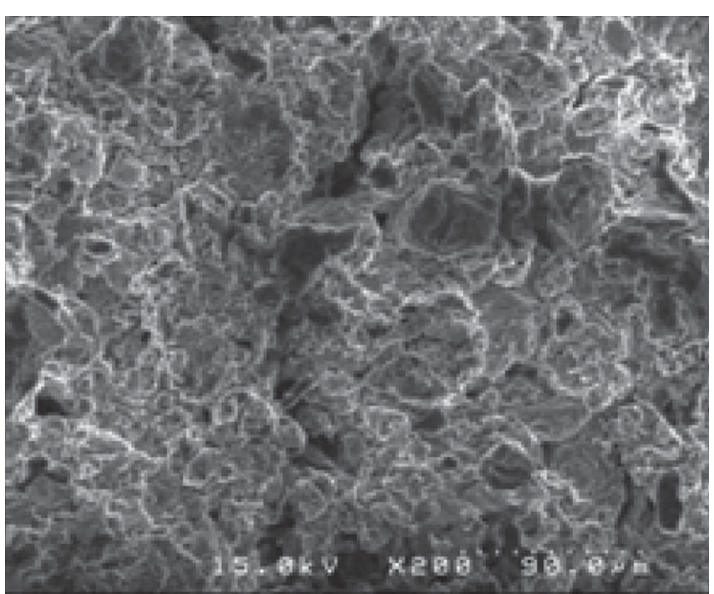

(b)

Fig. 7. SEM surface morphology of CR-P-N conductive coating (a) before and (b) after electrolysis test.

$0.168,0.102$ and $0.094 \mathrm{~mA} / \mathrm{cm}^{2}$, respectively. The electrical resistivities of the three specimens show an inverse proportionality between the initial and steady state current densities. The steady state current densities are lower than the initial current densities because the conductive coatings generate chlorine gas during electrolysis, which causes destruction of the conductive material surface, resulting in a lower current density. When the chlorine gas is unable to do further damage, the current density remains steady state. Figure 7 shows the SEM surface morphology of the PU-CG conductive coating before and after electrolysis test. The specimen after electrolysis test showed some cracks on surface as shown in Fig. 7(b). Another factor which affects the current density is that when the solution enters the coating it causes decreased conductivity. As the electric resistivity and conductive path are heavily related, when the resistivity is lowered, the current density reaches to steady state quickly.

Figure 8 shows the change in concentration of free chlorine during the electrolysis process. The concentration of free chlorine is theoretically directly proportional. As the current density is higher initially, the free chlorine generation rate is higher than the consumption rate.

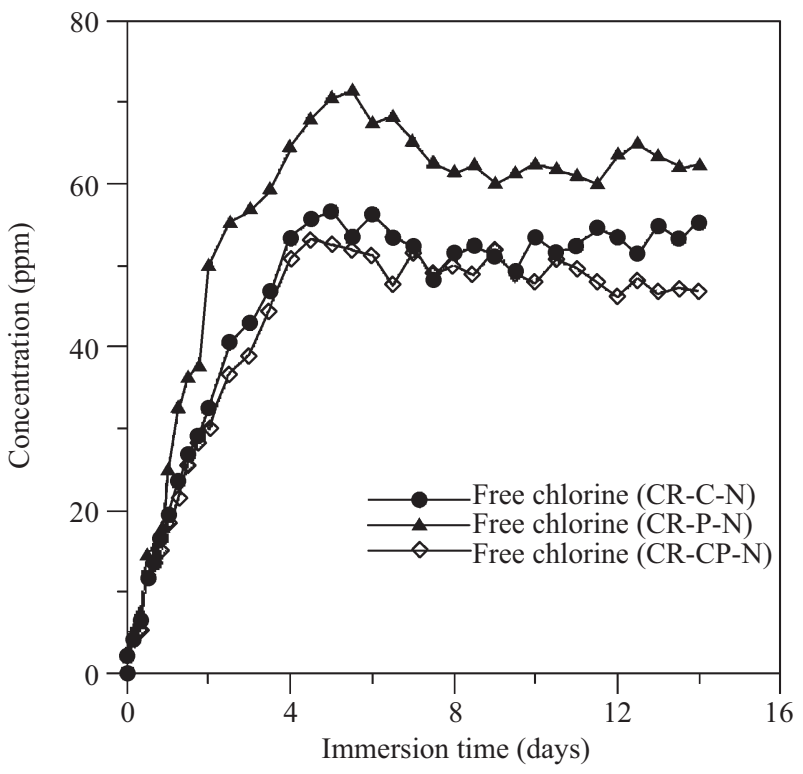

Fig. 8. The concentration of free chlorine generated at a constant anodic potential $(4 \mathrm{~V}, \mathrm{SCE})$ for conductive coatings in $3.5 \% \mathrm{NaCl}$ solution.

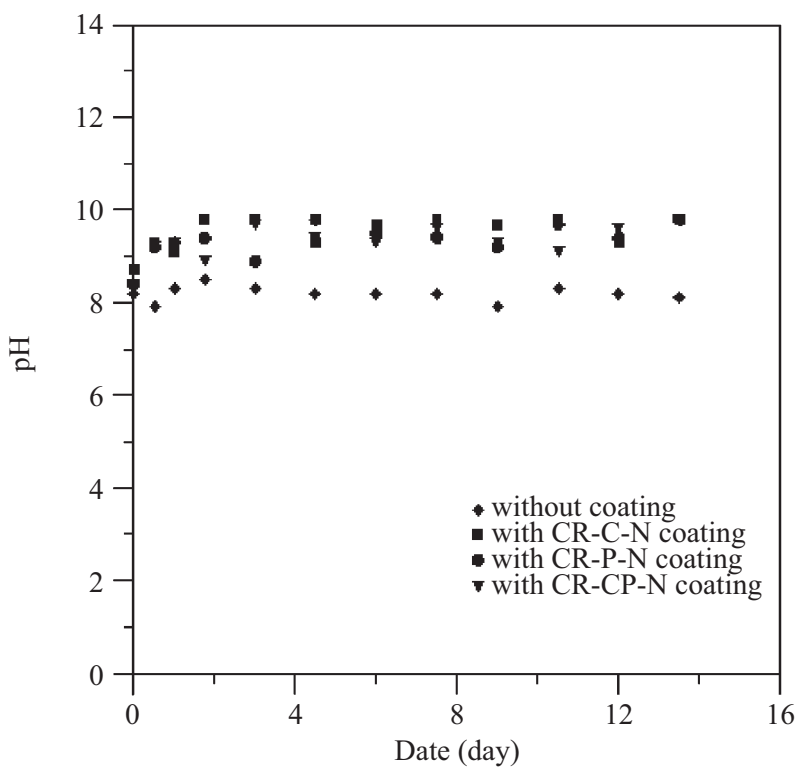

Fig. 9. The pH value at a constant anodic potential $(4 \mathrm{~V}, \mathrm{SCE})$ for conductive coatings in $3.5 \% \mathrm{NaCl}$ solution.

When the current density stabilizes, free chlorine concentrations reach equilibrium. The steady state concentrations of free concentrations are shown in Table 2.

Figure 9 shows the change in $\mathrm{pH}$ during the electrolysis investigation, which is maintained in the range 9-10. Fig. 1 shows that the generation of free chlorine is predominantly in the form of the hypochlorite ion and that the chlorine concentration is much higher than the effective methods from previous studies $[7,8,13]$ 


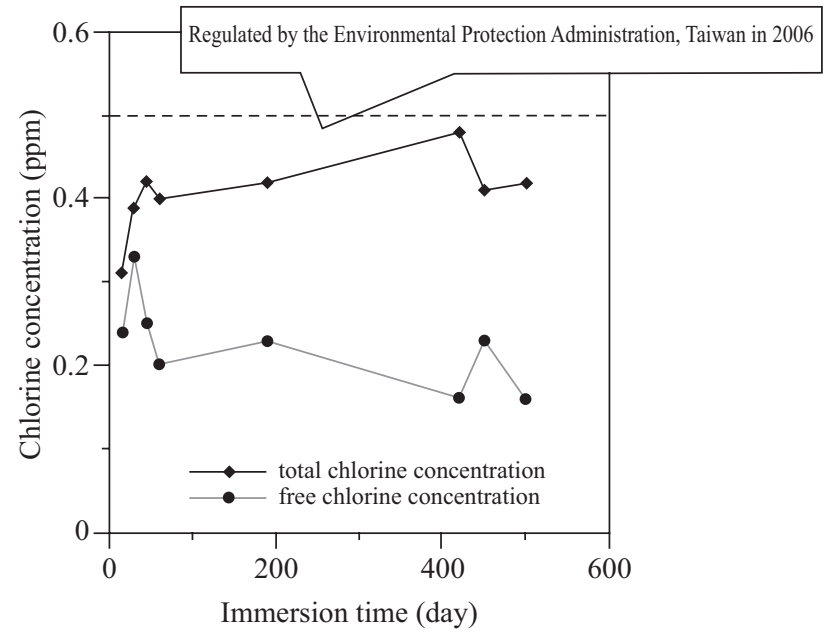

Fig. 10. The concentration of free chlorine and total chlorine generated during field testing.

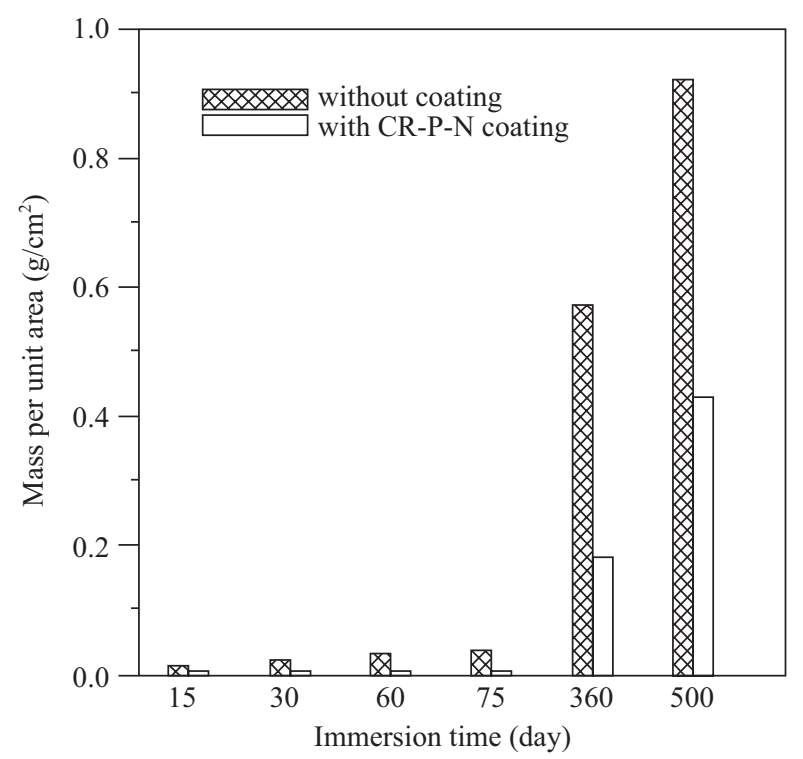

Fig. 11. Average dry weight of marine biofouling attached to the fishing net.

\section{Field Tests}

As CR-P-N performed most successfully, it was chosen for the field test. A solar energy board was used to supply a continuous voltage $(0.3-0.8 \mathrm{~V})$ for the long term field test. The measured concentration of free and total chlorine is shown in Fig. 10. Samples were taken from the coating surface approximately $10-15 \mathrm{~cm}$ apart; the final values of total chlorine concentration were less than the maximum value of $0.5 \mathrm{ppm}$ as regulated by the Environmental Protection Administration (Taiwan) in 2006 [5], suggesting that they will not pose a risk of pollution to the marine environment.

The fishing net was washed and then baked in an oven at $105^{\circ} \mathrm{C}$ for 24 hours to dry. The computational values of attached
Table 3. Mass of attached marine biofouling as a function of time in the field.

\begin{tabular}{|c|c|c|c|}
\hline $\begin{array}{c}\text { Immersion time } \\
(\text { day })\end{array}$ & $\begin{array}{c}\text { Without coating } \\
\left(\mathrm{g} / \mathrm{cm}^{2}\right)\end{array}$ & $\begin{array}{c}\text { With CR-P-N } \\
\left.\text { coating (g/cm }{ }^{2}\right)\end{array}$ & $\begin{array}{c}\text { Anti-fouling } \\
\text { efficiency }(\%)\end{array}$ \\
\hline 15 & 0.012 & 0.004 & 67 \\
\hline 30 & 0.024 & 0.004 & 83 \\
\hline 60 & 0.030 & 0.004 & 87 \\
\hline 75 & 0.036 & 0.006 & 83 \\
\hline 360 & 0.573 & 0.180 & 69 \\
\hline 500 & 0.921 & 0.430 & 53 \\
\hline
\end{tabular}

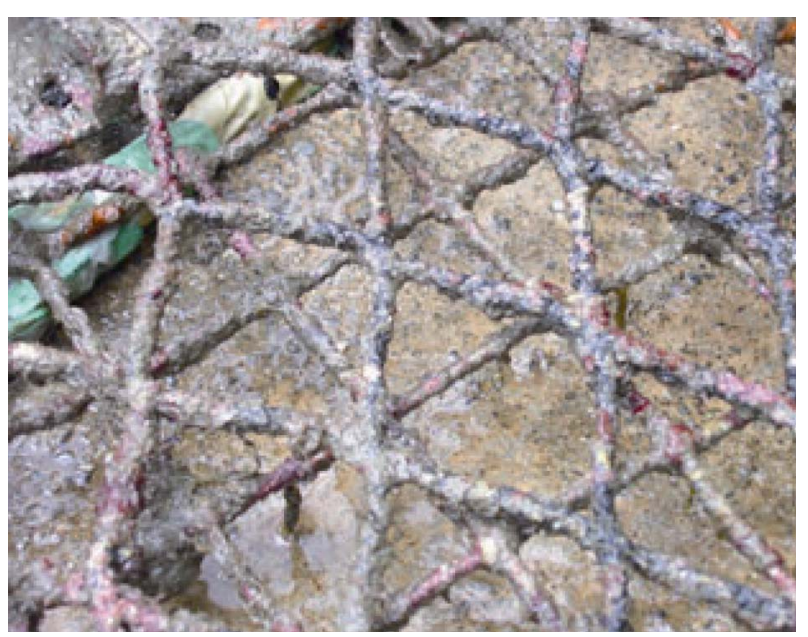

Fig. 12. The appearance of conductive rubber coatings (CR-P-N) after 500 days in the field test.

marine biofouling quantities are shown in Fig. 11. Comparisons of the CR-P-N coating with the control group after several time periods are shown in Table 3 and suggest that the inhibition ability lies at about $53-87 \%$.

The average mass of the marine biofouling materials attached to the control group and rubber coatings were 0.92 and $0.43 \mathrm{~g} / \mathrm{cm}^{2}$ respectively. The marine organisms were identified to be predominantly polychaetes, bryozoans and tunicates. The appearance of the conductive rubber coatings (CR-P-N) is shown in Fig. 12. The results suggest that the conductive rubber coatings have excellent antifouling properties as well as good durability.

\section{CONCLUSION}

1. The results of the laboratory electrical resistivity tests show that conductive rubber with polyaniline displays the greatest electrical conduction. The simultaneous addition of carbon black and polyaniline showed no benefit over polyaniline alone.

2. The conductive rubber coatings (CR-P-N) generated enough free chlorine to inhibit marine fouling (by about 53\%) after 500 days. The free and total chlorine concentrations during 
the tests were less than the maximum $0.5 \mathrm{ppm}$ regulated by the Environmental Protection Administration, Taiwan, and are therefore unlikely to create marine pollution.

3. The conductive coating (CR-P-N) adheres naturally to the cage and showed no flaking during the long-term field testing,

4. The conductive coatings can be applied to the cage aquaculture and set-net fisheries in order to inhibit marine biofouling pollution.

\section{ACKNOWLEDGMENTS}

The authors are grateful to Mr. Wen-Chi Chiang, Mr. ShangJu Liu and Mr. Chien-Chung Chen who participated in this study together, and financial sponsored of this research by the Council of Agriculture, Taiwan (Contract No. 93AS-9.1.1-F121).

\section{REFERENCES}

1. Alzieu, C., "Environmental problems caused by TBT in france: Assessment, regulations, prospects," Marine Environmental Research, Vol. 32, pp. 7-17 (1991).

2. Champ, M. A., "Economic and environmental impacts on ports and harbors from convention to ban harmful marine antifouling system," Marine Pollution Bulletin, Vol. 46, pp. 935-940 (2003).

3. Chiang, W. C., Chyou, S. D., Huang, R., and Wu, J. K., "Control of marine biofouling by conductive coatings," Corrosion Prevention and Control, Vol. 47, No. 4, pp. 121-128 (2000).

4. Duan, Y. P., Liu, S. H., and Guan, H. T., "Investigation of electrical conductivity and electromagnetic shielding effectiveness of polyaniline composite," Science and Technology of Advanced Materials, Vol. 6, pp. 513-518 (2005).

5. Environmental Protection Administration, Taiwan, Environmental Law, publushed on the World Wide Web at http://law.epa.gov.tw/en/ (2006).
6. Faez, R. and De Paoli, M. D., "A conductive rubber based on EPDM and polyaniline - 1. doping method effect," European Polymer Journal, Vol. 37, pp. 1139-1143 (2001).

7. Goodman, P. D., "Effect of chlorination on materials for seawater cooling systems: A review of chemical reactions," British Corrosion Journal, Vol. 22, pp. 56-62 (1987).

8. Gundersen, R., Johansen, B., and Gartland, P. O., "The effect of sodium hypochlorite on the electrochemical properties of stainless steels in seawater with and without bacterial films," Corrosion, Vol. 47, pp. 800-807 (1991).

9. Hodson, S. L., Burke, C. M., and Bissett, A. P., "Biofouling of fish-cage netting: The efficacy of a silicon coating and effect of netting colour," Aquaculture, Vol. 184, pp. 277-290 (2000).

10. Lewis, J. A., "Biofouling and fouling protection: A defense perspective," in: Kjelleberg, S. and Steunberg, P., (eds.), Biofouling: Problems and Solutions, Proceedings of an international workshop, The University of New South Wales, Sydney, Australia, pp. 39-43 (1994).

11. Lindner, E., "Low surface free energy fouling resistant coatings," in: Thompson, M. F., Nagahushananm, R., Sarojini, R., and Fingerman, M., (eds.), Recent Developments in Biofouling Control, A. A. Balkma, Rotterdam, pp. 305-319 (1994).

12. Nishi, A., Usami, M., Ueda, K., and Tomoshige, K., "Antifouling system for ship hull by electro-conductive coating," Mitsubishi Heavy Industries Ltd. Technical Review, Vol. 29, pp. 30-35 (1992).

13. Oldfield, J. W. and Todd, B., "Corrosion problems caused by bromine formation in MSF desalination plants", Desalination, Vol. 38, pp. 233246 (1981).

14. Regoli, L., Chan, H. M., De Lafontaine, Y., and Mikaelian, I., ”Organotins in zebra mussels (Dreissena Polymorpha) and sediments of the quebec city harbour area of the St. Lawrence river," Aquatic Toxicology, Vol. 53, pp. 115-126 (2001).

15. Swain, G. W., Griffith, J. R., Bultman, J. D., and Viencent, H. L., "The use of barnacle adhesion measurements for field evaluation of nontoxic foul release surfaces," Biofouling, Vol. 6, pp. 105-114 (1992).

16. Valensi, G., Deltombe, E., Zoubon, N. De Vanlengenhaghe, C., and Pourbaix, M., "Chlorine," Atlas of Electrochemical Equilibria in Aqueous Solutions, NACE, Houston, Texas, pp. 590-603 (1974).

17. Wang, X. H., Li, J., Zhang, J. Y., and Sun, Z. C., "Polyanilline as marine antifouling and corrosion prevention agent," Synthetic Metals, Vol. 102, pp. 1377-1380 (1999). 